\title{
HEALTH BENEFITS INDUCED BY ADHERENCE TO THE MEDITERRANEAN LIFESTYLE COMPONENTS DIET AND PHYSICAL ACTIVITY
}

\author{
Cécil J. W. MEULENBERG \\ Science and Research Centre Koper, Institute for Kinesiology Research, Slovenia \\ Corresponding author: \\ Cécil J. W. MEULENBERG \\ Science and Research Centre Koper, Institute for Kinesiology Research \\ Garibaldijeva 1, SI-6000 Koper, Slovenia \\ Phone: +38631424233 \\ E-mail: cecil.meulenberg@zrs-kp.si
}

\section{ABSTRACT}

The purpose of this overview is to present the evidence that adherence to Mediterranean lifestyle components is beneficial for functional and cognitive health. Although Mediterranean diet is the principal component of this lifestyle, other components, like physical activity and socializing, form complex interactions and together they complete into the Mediterranean lifestyle. Individual components and their interactions have not been studied thoroughly, however, there is an increasing attention for these matters through scientific literature in original research, reviews and meta-analysis. This paper considers the recent knowledge and trends related to defining the indicators concerning these lifestyle components, as well as summarizes the health benefits induced by adherence to them and explains why Mediterranean lifestyle components are important for health.

Keywords: lifestyle, Mediterranean diet, physical activity, health benefit, interactions. 


\section{PREHRANA IN GIBALNA AKTIVNOST KOT ZDRAVJU KORISTNI SESTAVINI SREDOZEMSKEGA ŽIVLJENJSKEGA SLOGA}

\section{IZVLE $\check{C} E K$}

Namen preglednega članka je predstaviti dosedanja dognanja o tem, kako lahko ima upoštevanje sredozemskega načina življenja dobrodejne učinke na funkcionalno in kognitivno zdravje posameznika. Medtem ko številni avtorji trdijo, da je sredozemska prehrana poglavitna sestavina zdravega načina življenja, le ta z drugimi dejavniki, kot so gibalna aktivnost in bogato socialno življenje, tvori zapletene interakcije in skupaj z njimi dopolnjuje sredozemski način življenja. Posamezne komponente in njihov medsebojni vpliv še niso popolnoma raziskane, vendar pa jim raziskovalci v izvirnih znanstvenih raziskavah, preglednih člankih in meta-analizah, posvečajo vedno več pozornosti. Prispevek obravnava najnovejša dognanja in trende v zvezi z opredelitvijo kazalcev omenjenih komponent sredozemskega življenjskega sloga, poleg tega pa pojasnjuje tudi, zakaj so sredozemske sestavine življenjskega sloga tako pomembne za zdravje.

Ključne besede: življenjski slog, sredozemska prehrana, telesna dejavnost, zdravje, interakcije

\section{INTRODUCTION}

The attention to the possible benefit for health of the diet and the lifestyle typical of Mediterranean countries came from the "seven countries study". Started in 1947 by Ancel Keys and co-workers the study compared diet and lifestyles in the USA, Finland, Yugoslavia, Japan, the Netherlands, Italy and Greece, and led to the discovery that Italy, Greece and Yugoslavia (particularly the coastal region of Croatia) had a much lower incidence of non-communicable degenerative diseases (Keys, Fidanza, Karvonen, Kimura \& Taylor, 1972). Later on, Ancel Keys and his co-workers settled in Italy in the small village of Pioppi, south of Naples, and deeply analysed the lifestyle and the food choice not only in Italy but also in Greece (particularly on the island of Crete), Spain, Portugal and Croatia. From their work, the foundation of the concept of Mediterranean diet and lifestyles were set (Keys et al., 1986). Unfortunately, in those countries, 60 years later, the traditional way of eating and the healthy lifestyles have been cancelled, to a great extent due to homogenization of dietary choices and living habits typical of the global economy (Bach-Faig et al., 2011; Martinez-Lacoba, Pardo-Garcia, Amo-Saus \& Escribano-Sotos, 2018). 


\section{CHARACTERISTICS OF MEDITERRANEAN DIET}

Mediterranean diet within the scientific fields of dietetics, nutrition and food technology is predominantly handled as a traditional dietary pattern with a focus on its constituents (e.g., Bach et al., 2006; Katz \& Meller, 2014; Davis, Bryan, Hogson \& Murphy, 2015). It is plant-based with freshly-harvested vegetables, fruits, nuts and seeds, beans and legumes, many herbs and spices, and whole grains. With frequent consumption of fish and other sea foods, selective dairy intake and quite limited consumption of meat, eggs and sweets, but emphasizing the use and consumption of healthful fats like extra virgin olive oils and fishy fats, and moderate amounts of (red) wine.

The Mediterranean diet is not an homogeneous model globally nor within the Mediterranean area, as it is highly dependent on the region, and influenced by socio-cultural, religious and economic factors (Bach et al., 2006). Despite these regional variations, the average nutrient content of the diet is relatively consistent among various studies (Davis et al., 2015). For eight studies the percentage of total daily energy (9.3 MJoule) was as follows: $37 \%$ as fat of which $5 \%$ polyunsaturated, $19 \%$ monounsaturated, and $9 \%$ saturated (note the ratio of 2 for unsaturated to saturated); $15 \%$ protein; $43 \%$ carbohydrate; with for some constituents: fibre $33 \mathrm{~g} /$ day, vitamin C $225 \mathrm{mg}$ /day and folate $508 \mu \mathrm{g} /$ day. Thus, the diet promotes high intake of fibre, results in a favourable ratio of omega-6 and omega-3 essential fatty acids (Trichopoulou et al., 2014; Davis et al., 2015), and especially increases the non-enzymatic antioxidant capacity through the consumption of antioxidants and polyphenols from extra virgin olive oil (Zamora-Ros et al., 2013).

\section{MEDITERRANEAN DIET-INDUCED HEALTH EFFECTS}

The combination of foods and the content of nutrient constituents made the Mediterranean diet a subject of many scientific studies, that investigated the potential health effect during the intervention by Mediterranean eating (reviewed by Sofi, Macchi, Abbate, Gensini \& Casini, 2014; Martinez-Lacoba et al., 2018). An early systematic review by Serra-Majem, Roman and Estruch (2006) investigated 35 experimental studies referring to the Mediterranean diet as an intervention and showed favourable effects on lipoprotein levels, endothelium-dependent vasodilatation, insulin resistance, metabolic syndrome, antioxidant capacity, myocardial and cardiovascular mortality, and cancer incidence. Moreover, Sofi et al. showed by analysing 18 cohort prospective studies that adherence to the Mediterranean diet for three to 18 years reduced the risk of overall mortality, with a clear reduction of the incidence for cardiovascular, cancer, and neurodegenerative diseases and stroke (Sofi, Cesari, Abbate, Gensini \& Casini, 2008; Sofi, Abbate, Gensini \& Casini, 2010). In recent years, these beneficial health effects have been confirmed, namely in the form of improved insulin sensitivity (Ryan et al., 2013), reduced cancer risk (Giacosa et al., 2013), and particularly well-demonstrated the reduced risk of cardiovascular diseases (de Lorgeril \& Salen, 2006; 2011; Ibarrola- 
Jurado et al., 2011; Nordmann et al., 2011; Bonaccio et al., 2018; Estruch et al., 2018). Lower prevalence of general obesity and metabolic syndrome has been shown (Ibarrola-Jurado et al., 2011), and also the improvement of quality of life and diminished pulmonary inflammation in asthmatic patients (Sexton et al., 2013; Papamichael, Itsiopoulos, Susanto \& Erbas, 2017; Papamichael et al., 2018). Finally, higher adherence to a Mediterranean diet was associated with a reduction in mortality (Trichopoulou, Bamia \& Trichopoulos, 2009; Bonaccio et al., 2018). Thus, in conclusion, adherence to the Mediterranean diet, the plant-based diet as described above, seems to provide longevity with a reduced risk for chronic non-communicable diseases.

\section{DIET AS PART OF MEDITERRANEAN LIFESTYLE}

Long and healthy (functional and cognitive) ageing is of importance to humans as a species, and perhaps these health benefits attributed to the diet, in combination with where, and in which cultural environmental settings the diet is embedded, were the reasons that in 2010 the Mediterranean diet got inscribed in the UNESCO representative list of intangible cultural heritage of humanity (UNESCO, 2010).

On UNESCO's webpages, one can find the following description: 'The Mediterranean diet involves a set of skills, knowledge, and traditions concerning crops, harvesting, fishing, animal husbandry, conservation, processing, cooking, and particularly the sharing and consumption of food. Eating together is the foundation of the cultural identity and continuity of communities throughout the Mediterranean basin. It is a moment of social exchange and communication, an affirmation and renewal of family, group or community identity. The Mediterranean diet emphasizes values of hospitality, neighbourliness, intercultural dialogue and creativity, and a way of life guided by respect for diversity.'

These writings clearly emphasize a particular social ensemble of traits that centres around food production, harvesting and consumption, guided by the Mediterranean climate and region. An update by the Mediterranean Diet Foundation Expert Group (Bach-Faig et al., 2011), additionally adds to emphasize sobriety and moderation, with inclusion of cultural and lifestyle components that are based on the Mediterranean diet pyramid, such as conviviality, culinary activities, adequate rest, and physical activity. Mediterranean diet, when used in dietetics or nutritional sciences, often refers to the plant-based and micronutrient-balanced diet, while often, in the wider scientific fields like the social sciences, or in specific fields like kinesiology, this UNESCO-recognized Mediterranean intangible heritage as such, should be, more appropriately, referred to as Mediterranean lifestyle.

UNESCO, the Scientific Committee of the International Foundation of Mediterranean Diet and others acknowledge the specific lifestyle characteristics (Sotos-Prieto et al., 2015; Yannakoulia, Kontogianni, \& Scarmeas, 2015; Dernini et al., 2017). They indicate that such lifestyle components are worth being identified (Bach et al., 2006), as they might be valuable to human health and heritage. 


\section{BRAIN HEALTH INFLUENCED BY MEDITERRANEAN LIFESTYLE COMPONENTS}

Brain function, overwhelmingly studied, is a good example to demonstrate its dependence on lifestyle components. In relation to Mediterranean lifestyle components beneficial to cognitive health, next to adherence to the diet, Yannakoulia et al. (2015) particularly mention the participation in leisure activities, social interaction, physical activity and the quality of sleep. Each of these factors have been individually demonstrated to effectively maintain better cognitive performance, promote healthy cognitive ageing, reduce depressive symptoms, and delay neurodegeneration (e.g., Polidori, Nelles \& Pientka, 2010; Schreiber et al., 2016; Clare et al., 2017; Kivipelto, Mangialasche \& Ngandu, 2018; Zhao et al., 2018).

Sofi et al. came to the conclusion (Sofi et al., 2008; 2010) that the adherence to the Mediterranean diet reduced mild cognitive impairment and the risk to undergo Parkinson's and Alzheimer's diseases. More recent studies confirm that higher adherence to the Mediterranean diet is associated with improved cognition (Féart et al., 2009; Martínez-Lapiscina et al., 2013; Ye et al., 2013), assessed through, amongst others, Mini Mental State Examinations and the clock drawing tests. Adherence to the Mediterranean diet thus establishes lower risk of cognitive impairment (Ye et al., 2013; Gardener et al., 2015), it reduces the risk of Alzheimer's disease (Scarmeas et al., 2006), and induces better performance in the executive function domain (Gardener et al., 2015).

The positive impact of the Mediterranean diet on brain health is detectable also at morphological level. Among 672 cognitively normal participants from the U.S.A., with an average of 79.8 years of age, higher adherence to the Mediterranean diet was associated with larger frontal, parietal, occipital, and average cortical thickness (Staubo et al., 2017). In line with this, among 400 Scottish elderly persons, a low adherence to the Mediterranean diet predicted brain atrophy (Luciano et al., 2017). A study with 4447 participants in the Netherlands showed that a higher diet quality, especially the one that abode by the Mediterranean diet, was associated with larger overall and hippocampal brain tissue volumes (Croll et al., 2018). Similarly, among 459 participants in the United Kingdom, a higher and prolonged adherence (over 11 years) to guidelines for healthy diet was associated with larger hippocampal volume (Akbaraly et al., 2018). These studies clearly indicate that diet itself affects brain volume and structure.

Further, higher adherence to the Mediterranean diet has been shown to reduce the incidence of depression from a meta-analysis among 20 longitudinal and 21 crosssectional studies (Lassale et al., 2018), and in addition, a diet with a low potential to induce inflammation, was associated with lower depression incidence in four longitudinal studies (Lassale et al., 2018). A recent randomized controlled trial showed that a 12-week intervention with Mediterranean diet significantly reduced the symptoms of major depression (Jacka et al., 2017). Thus, as for functionality of the brain, a condition as behaviour in the form of depression, is clearly influenced by diet as well. Presumably, it is influenced in both directions, depending on the quality of diet. 
Moreover, a healthy diet maintains a healthy balanced intestinal microbiota (Cryan \& Dinan, 2012; Dash, Clarke, Berk \& Jacka, 2015; Johnson \& Foster, 2018), and research indicates that this symbiosis establishes an intestines-brain axis, and is of major support to the health of the brain, by influencing the development of the brain, as well as behaviour and mood. Interestingly, in the intestines, the microbial fermentation of host-indigestible dietary fibres produces short-chain fatty acids that act as signals in the host (Kelly, Minuto, Cryan, Clarke \& Dinan, 2017; Johnson \& Foster, 2018). Supplementation of such fatty acids to mice has been shown to alleviate selective and enduring alterations induced by repeated psychosocial stress (van de Wouw et al., 2018). Such fatty acids are not the only products from the presence of microbiota that can influence the host's endocrine signalling. Not even closely do we have proper understanding of the microbiota-intestines-brain axis.

Continuing to reason along this axis, which means drawing associations between the consumption of specific foods and brain health might seem far-fetched. The examples of depression studies mentioned in the previous paragraph make it very plausible for food (the microbiota-intestine-brain axis) to affect our mood and behaviour. Besides, the following examples emphasize this importance. There is established evidence that altered microbiota populations exist in human patients with autism spectrum disorders, schizophrenia, depression and obesity, compared to unaffected patients and can contribute to (brain) inflammation as well (Cryan \& Dinan, 2012; Dash et al., 2015; Kelly et al., 2017; Johnson \& Foster, 2018). Another accent comes from a recent large cohort, in which removal of the vermiform appendix - that hosts microbiota, pathogens and immune cells - decades before the onset of Parkinson's disease, lowers the risk of obtaining Parkinson's disease (Killinger et al., 2018). Even more interesting is the fact that bacteria are presumed to live in our brains during our life (Roberts, Farmer \& Walker, 2018). Altogether, food consumption not only determines the quantity and quality of the micronutrients available to the host, but influences the contamination of the host with microorganisms and potential symbioses as well, consequently having effect on the host by the microorganism's metabolism and the production of endocrine signals.

Brain health is a complex matter and dependent on various lifestyle factors. The same can be claimed about human health in general. Finding the palette for optimal living requires identifying the details, relations and synergies of lifestyle components.

\section{HOW TO MEASURE ADHERENCE TO THE MEDITERRANEAN LIFESTYLE}

To measure adherence to the Mediterranean diet, questionnaires on food consumption frequency have been used. In general, when conducting population-based prospective investigations, the participants are invited to complete extensive, validated, food or physical-activity frequency questionnaires at baseline. During the follow-up, adherence is assessed by multiple-items scales that incorporate salient characteristics of both eating habits and/or physical activity patterns. Usually, the populations' range 
of the scores and the higher scores, describe the population's greater adherence to the topic or lifestyles of interest.

More recently, in order to assess adherence to lifestyle-habits, Sotos-Prieto et al. (2015) designed the 28-indicator Mediterranean lifestyle (MEDLIFE) index that additionally included physical activity patterns, adequate rest, social interactions and conviviality. Expanding on the MEDLIFE index, and beyond the obvious category (1) health and nutritional benefits, Dernini et al. (2017) characterized the multiple dimensions and benefits of the Mediterranean lifestyle through a methodological framework (Med Diet 4.0). It identifies and recognizes country-specific and culturally appropriate variations, i.e., regional food diversity, making a future-derived scale internationally applicable. Additionally, the framework introduces several sustainability categories and proposes to assess specific indicators for benefits in additional areas: (2) richness in biodiversity and low environmental impact; (3) high social and cultural food values; and (4) positive local economic returns. The framework is described by the Scientific Committee of the International Foundation of Mediterranean Diet (Dernini et al., 2017) and would be of special interest as it describes a wider lifestyle with various components, but up till now a practical index has not been tested.

The 24-hour dietary recall (Thompson \& Byers, 1994), the questionnaires on food consumption frequency (Sampson, 1985), together with the recent scales and frameworks like MEDLIFE (Sotos-Prieto et al., 2015) and the Med Diet 4.0 (Dernini et al., 2017) are easily implemented. Especially the latter two would facilitate the comparison of studies that investigate adherence to the Mediterranean lifestyle and the contributing interrelated lifestyle components (Bach et al., 2006). Such comparison is important for understanding the quality of human life (both in health and of footprint), and the identification of common and/or cultural-specific lifestyle components, that could gain attention and thus might find a way of becoming tangible heritage.

\section{MEDITERRANEAN LIFESTYLE INTERVENTIONS}

The state of health across the lifespan - during childhood, adolescence and old age - is a product of the cumulative factors experienced (Calder et al., 2018). In general, a healthy diet with the specific distribution and prevalence of physical and sedentary activities influence physiological and metabolic functions that altogether determine disease, cognition and functionality (Calder et al., 2018; Martin et al., 2018). However, the interactions of such components are poorly studied. Therefore, the following sections of this paper will recapitulate the details of various systematic reviews that include meta-analysis of randomized controlled trials (or cohorts), where adherence to the components 1) physical activity and 2) Mediterranean diet, were addressed as an intervention, either separately or in combination. 


\section{MEDITERRANEAN DIET AS AN INTERVENTION}

In relation to health benefits induced by Mediterranean diet as an intervention, Kastorini et al. (2011) reviewed 35 clinical trials and Garcia et al. (2016) reviewed 29 randomized controlled trials. Both reviews showed that waist circumference was significantly reduced, while also systolic and diastolic blood pressures, blood glucose and triglycerides levels were significantly reduced with adherence to the Mediterranean diet. High-density lipoprotein cholesterol levels were increased as reported by Kastorini et al. (2011), although no change was observed by Garcia et al. (2016). Both reviews showed that adherence to the Mediterranean diet positively effects the biomarkers linked to the metabolic syndrome, especially for interventions longer than 3 months in duration. Interestingly, it was mentioned that adherence to the Mediterranean diet was significantly beneficial when the study was of high quality and the intervention was longer in duration (Kastorini et al., 2011; Garcia et al., 2016), besides, it was conducted in Europe (Garcia et al., 2016).

Esposito, Kastorini, Panagiotakos and Giugliano (2011) reviewed 16 randomized controlled trials, 1 to 24 months in duration, were Mediterranean diet was used as an intervention compared to a control diet. The Mediterranean diet groups showed greater reductions in body weight and body mass index for trials longer than 6 months in duration, while the effect was larger in association with increased physical activity or energy restriction. Thus, typically none of the studies reported weight gain with adherence to a Mediterranean diet more than 6 months in length, which made the authors conclude that Mediterranean diet is useful as an intervention targeted to lose weight (Esposito et al., 2011), despite the diet being high in fat of predominantly extra virgin olive oils origin.

\section{PHYSICAL ACTIVITY AS AN INTERVENTION}

Despite the fact that plenty of intervention studies based on physical activity are available in the scientific literature, the current discussion restricts itself to the most relevant systematic reviews and meta-analysis of randomized controlled trials.

Physical activity as an intervention during randomized controlled trials was reviewed by Kodama et al. (2007) who identified 25 intervention studies with an average length of about 7 months. Aerobic training resulted in increases of high-density lipoprotein cholesterol levels (Kodama et al., 2007), with no association between exercise frequency or intensity. Strasser, Siebert and Schobersberger (2010) identified 13 randomized controlled trials, in which the effect of physical resistance training on average 3 times a week for 1.5 to 12 months, was compared between a control group and patients with abnormal glucose regulation. The physical activity reduced the fat mass and systolic blood pressure (Strasser et al., 2010), while no statistically significant effects on total cholesterol, high- and low-density lipoprotein cholesterol, triglycerides and diastolic blood pressure were observed. Further, Cornelissen and Smart (2013) identified 93 trials and showed that physical activity as endurance, dynamic resistance, 
and isometric resistance training lowered both systolic and diastolic blood pressures for interventions smaller than 6 months. Whereas interventions longer than 6 months induced smaller reductions in blood pressures, and the combination of these types of physical training lowered only diastolic blood pressure (Cornelissen \& Smart, 2013). Lin et al. (2015) identified 29 randomized controlled trials with physical activity as an intervention with a medium duration of 3 months. It was shown that exercise significantly improved cardiorespiratory fitness and lowered the levels of fasting insulin, triglycerides and leptin, while increasing the levels of both high-density lipoprotein cholesterol and apolipoprotein A1, and interleukin-18. The effects of physical activity were more pronounced in persons over 50 years of age, men, and persons suffering from type 2 diabetes, hypertension and metabolic syndrome.

Physical activity improves the blood pressure regardless of the type of exercise, and, just like diet, positively influences the indicators of metabolic syndrome.

\section{CONCURRENT PHYSICAL ACTIVITY AND MEDITERRANEAN DIET AS AN INTERVENTION}

Recently, the randomized controlled trials assessing overall health resulting from the combined intervention, physical activity and adherence to Mediterranean diet, were systematically reviewed (Malakou et al., 2018). This meta-analysis identified 11 randomized controlled trials executed between 2003 and 2017, of which the intervention duration lasted from 2 months to 6 years. The combined intervention reduced body weight, body mass index, waist circumference, both systolic and diastolic blood pressures, while as well reducing the levels of blood glucose, triglycerides and total cholesterol, and increasing the high-density lipoprotein cholesterol levels. No evidence of an effect on insulin concentrations was found. Although the authors mention the high degree of heterogeneity between the results from the trials, and the need for welldesigned and thoroughly executed randomized controlled trials, the combination of Mediterranean diet and physical activity as an intervention clearly provides a reduction in weight (especially with interventions shorter than 12 months in duration), and a reduced metabolic syndrome risk.

Interestingly, Malakou et al. (2018) mention that none of the randomized controlled trials compare the combined effect against control groups receiving only physical activity, Mediterranean diet or no treatment respectively. Only two studies compared the combined intervention results with usual control group (Droste et al., 2013; Dunn, Siu, Freund \& Boutcher, 2014) and found a reduced metabolic syndrome risk for the combined intervention. Still, it is not clear whether a synergistic effect of the concurrent interventions exists.

In addition, the results of recent studies seem to suggest that there are synergistic effects. In the U.S.A., out of 170.672 women and men aged 51 to 71 years at baseline in 1996/1997 and followed-up in 2009, adhering to high physical activity levels and Mediterranean diet, was associated with lower risk of mortality than groups only ad- 
hering to physical activity recommendations or only following the Mediterranean diet (Behrens et al., 2013). In a study in Spain, among 19.467 female and male university graduates aged 27 to 46 years of age at baseline in 1999 and followed-up in 2016, similar results were found (Alvarez-Alvarez et al., 2018a). More specifically, the combination of interventions showed a reduced risk for cardiovascular disease as compared to the physical activity or Mediterranean diet separately (Alvarez-Alvarez et al., 2018b).

In combination with these epidemiological studies, it is concluded that adherence to a Mediterranean lifestyle, and most likely the individual Mediterranean lifestyle components, high physical activity and richly consuming the plant-based Mediterranean diet, will provide better health perspectives. This seems additionally true for living out of the geographical region from which the Mediterranean diet is originating.

\section{CONCLUSIONS}

Mediterranean lifestyle seems to be the palette we should strive to adhere to. It incorporates diet, physical activity and other lifestyle components, all worth promoting publicly for all ages. Health benefits, only induced by its components of diet and physical activity, seem numerous: increasing general and cognitive health with a reduced risk for non-communicable diseases, especially metabolic syndrome. However, further studies are needed that will investigate the synergy effects of combined components that determine the essential, effect-inducing, interactions between the Mediterranean lifestyle components. This can be done by thoroughly planned randomized controlled trials, using the established scales to assess the adherence, and the proper inclusion of multiple control groups.

For adults, the World Health Organisation recommends a minimum of 150 minutes of moderate-intense physical activity throughout the week. The International Society for Nutritional Psychiatry Research, recognizes diet and nutrition as central determinants of both physical and mental health, referred to as nutritional or orthomolecular medicine (Zell \& Grundmann, 2012; Sarris et al., 2015), with a recent success story that concerns the reversing of cognitive decline (Bredensen, 2017). The Mediterranean lifestyle embraces these recommendations. Besides, it promotes outdoor physical activities, organic food consumption, and sustainable novel food production.

Thus, the adherence to the Mediterranean lifestyle can nowadays be geographically applicable anywhere, and it gives the opportunity for practitioners, care givers and the public to create and adopt to more personalized nutritional and functional therapy, resulting in a better general health. 


\section{Acknowledgement}

This manuscript was prepared as part of the research programme Kinesiology for Quality of Life (P5-0381) funded by the Slovenian Research Agency.

\section{REFERENCES}

Akbaraly, T., Sexton, C., Zsoldos, E., Mahmood, A., Filippini, N., Kerleau, C., ... Kivimaki, M. (2018). Association of long-term eiet quality with hippocampal volume: Longitudinal cohort study. American Journal of Medicine, 131(11), 1372-1381. https://doi. org/10.1016/j.amjmed.2018.07.001.

Alvarez-Alvarez, I., Zazpe, I., Pérez de Rojas, J., Bes-Rastrollo, M., Ruiz-Canela, M., Fernandez-Montero, A., ... Martínez-González, M. A. (2018a). Mediterranean diet, physical activity and their combined effect on all-cause mortality: The Seguimiento Universidad de Navarra (SUN) cohort. Preventive medicine, 106, 45-52. https://doi. org/10.1016/j.ypmed.2017.09.021.

Alvarez-Alvarez, I., Pérez de Rojas, J., Fernandez-Montero, A., Zazpe, I., RuizCanela, M., Hidalgo-Santamaría, M., ... Martínez-González, M. A. (2018b). Strong inverse associations of Mediterranean diet, physical activity and their combination with cardiovascular disease: The Seguimiento Universidad de Navarra (SUN) cohort. European journal of preventive cardiology, 25(11), 1186-1197. https://doi. org/10.1177/2047487318783263.

Bach, A., Serra-Majem, L., Carrasco, J. L., Roman, B., Ngo, J., Bertomeu, I., \& Obrador, B. (2006). The use of indexes evaluating the adherence to the Mediterranean diet in epidemiological studies: a review. Public health nutrition, 9(1A), 132-146. https://doi. org/10.1079/PHN2005936.

Bach-Faig, A., Berry, E. M., Lairon, D., Reguant, J., Trichopoulou, A., Dernini, S., et al. (2011). Mediterranean diet pyramid today. science and cultural updates. Public health nutrition, 14(12A), 2274-2284. https://doi.org/10.1017/S1368980011002515.

Behrens, G., Fischer, B., Kohler, S., Park, Y., Hollenbeck, A. R., \& Leitzman, M. F. (2013). Healthy lifestyle behaviors and decreased risk of mortality in a large prospective study of U.S. women and men. European journal of epidemiology, 28(5), 361-372. https://doi.org/10.1007/s10654-013-9796-9.

Bonaccio, M., Di Castelnuovo, A., Costanzo, S., Gialluisi, A., Persichillo, M., Cerletti, C., ... Iacoviello, L. (2018). Mediterranean diet and mortality in the elderly: a prospective cohort study and a meta-analysis. British journal nutrition, 120(8), 841-854. https:// doi.org/10.1017/S0007114518002179.

Bredensen, D. (2017). The end of Alzheimer's: The first program to prevent and reverse cognitive decline. New York: Avery.

Calder, P. C., Carding, S. R., Christopher, G., Kuh, D., Langley-Evans, S. C., \& McNulty, H. (2018). A holistic approach to healthy ageing: how can people live longer, healthier lives? Journal of human nutrition and dietetics. 31(4), 439-450. https://doi. org/10.1111/jhn. 12566 .

Clare, L., Wu, Y. T., Teale, J. C., MacLeod, C., Matthews, F., Brayne, C., \& Woods, B. (2017). Potentially modifiable lifestyle factors, cognitive reserve, and cognitive func- 
tion in later life: a cross-sectional study. PloS medicine, 14(3), e1002259. https://doi. org/10.1371/journal.pmed.1002259.

Cornelissen, V. A., \& Smart, N. A. (2013). Exercise training for blood pressure: A systematic review and meta-analysis. Journal of the American heart association, 2(1), e004473. https://doi.org/10.1161/JAHA.112.004473.

Croll, P. H., Voortman, T., Ikram, M. A., Franco, O. H., Schoufour, J. D., Bos, D., \& Vernooij, M. W. (2018). Better diet quality relates to larger brain tissue volumes: The Rotterdam study. Neurology, 90(24), e2166-e2173. https://doi.org/10.1212/ WNL.0000000000005691.

Cryan, J. F., \& Dinan, T. G. (2012). Mind-altering microorganisms: the impact of the gut microbiota on brain and behaviour. Nature reviews neuroscience, 13(10), 701-712. https://doi.org/10.1038/nrn3346.

Dash, S., Clarke, G., Berk, M., \& Jacka, F. N. (2015). The gut microbiome and diet in psychiatry: focus on depression. Current opinion in psychiatry, 28(1), 1-6. https://doi. org/10.1097/YCO.0000000000000117.

Davis, C., Bryan, J., Hodgson, J., \& Murphy, K. (2015). Definition of the Mediterranean diet: A literature review. Nutrients, 7(11), 9139-9153. https://doi.org/10.3390/ nu7115459.

de Lorgeril, M., \& Salen, P. (2006). The Mediterranean diet in secondary prevention of coronary heart disease. Clinical investigative medicine, 29(3), 154-158.

de Lorgeril, M., \& Salen, P. (2011). The Mediterranean diet in secondary prevention of CHD. Public health nutrition, 14(12A), 2333-2337. https://doi.org/10.1017/ S136898001100259X.

Dernini, S., Berry, E. M., Serra-Majem, L., La Vecchia, C., Capone, R., Medina, F. X., ... Trichopoulou, A. (2017). Med Diet 4.0: the Mediterranean diet with four sustainable benefits. Public health nutrition, 20(7), 1322-1330. https://doi.org/10.1017/ S1368980016003177.

Droste, D. W., Iliescu, C., Vaillant, M., Gantenbein, M., De Bremaeker, N., Lieunard, C., ... Chioti, A. (2013). A daily glass of red wine associated with lifestyle changes independently improves blood lipids in patients with carotid arteriosclerosis: Results from a randomized controlled trial. Nutrition journal, 12(1), 147. https://doi.org/10.1186/14752891-12-147.

Dunn, S. L., Siu, W., Freund, J., \& Boutcher, S. H. (2014). The effect of a lifestyle intervention on metabolic health in young women. Diabetes, metabolic syndrome and obesity, 7, 437-444. https://doi.org/10.2147/DMSO.S67845.

Esposito, K., Kastorini, C. M., Panagiotakos, D. B., \& Giugliano, D. (2011). Mediterranean diet and weight loss: Meta-analysis of randomized controlled trials. Metabolic syndrome related disorders, 9(1), 1-12. https://doi.org/10.1089/met.2010.0031.

Estruch, R., Ros, E., Salas-Salvadó, J., Covas, M.-I., Corella, D., Arós, F., ... MartínezGonzález, M. A. (2018). Primary prevention of cardiovascular disease with a Mediterranean diet supplemented with extra-virgin olive oil or nuts. New England journal of medicine, 378(25), e34. https://doi.org/10.1056/NEJMoa1800389.

Féart, C., Samieri, C., Rondeau, V., Amieva, H., Portet, F., Dartigues, J. F., ... Barberger-Gateau, P. (2009). Adherence to a Mediterranean diet, cognitive decline, and risk of dementia. JAMA, 302(6), 638-648. https://doi.org/10.1001/jama.2009.1146. 
Garcia, M., Bihuniak, J. D., Shook, J., Kenny, A., Kerstetter, J., \& Huedo-Medina, T. B. (2016). The effect of the traditional Mediterranean-style diet on metabolic risk factors: A meta-analysis. Nutrients, 8(3), 168. https://doi.org/10.3390/nu8030168.

Gardener, S. L., Rainey-Smith, S. R., Barnes, M. B., Sohrabi, H. R., Weinborn, M., Lim, Y. Y., ... Martins, R. N. (2015). Dietary patterns and cognitive decline in an Australian study of ageing. Molecular psychiatry, 20(7), 860-866. https://doi.org/10.1038/ mp.2014.79.

Giacosa, A., Barale, R., Bavaresco, L., Gatenby, P., Gerbi, V., Janssens, J., ... Rondanelli, M. (2013). Cancer prevention in Europe: the Mediterranean diet as a protective choice. European journal of cancer prevention, 22(1), 90-95. https://doi.org/10.1097/ CEJ.0b013e328354d2d7.

Ibarrola-Jurado, N., Bulló, M., Guasch-Ferré, M., Ros, E., Martínez-González, M. A., Corella, D., ... Salas-Salvadó, J. (2013). Cross-sectional assessment of nut consumption and obesity, metabolic syndrome and other cardiometabolic risk factors: the PREDIMED study. PloS One, 8(2), e57367. https://doi.org/10.1371/journal.pone.0057367.

Jacka, F. N., O‘Neil, A., Opie, R., Itsiopoulos, C., Cotton, S., Mohebbi, M., ... Berk, M. (2017). A randomised controlled trial of dietary improvement for adults with major depression (the 'SMILES' trial). BMC medicine, 15(23), 1-13. https://doi.org/10.1186/ s12916-017-0791-y.

Johnson, K. V., \& Foster K. R. (2018). Why does the microbiome affect behaviour? Nature reviews microbiology, 16(10), 647-655. https://doi.org/10.1038/s41579-018-0014-3.

Kastorini, C. M., Milionis, H. J., Esposito, K., Giugliano, D., Goudevenos, J. A., \& Panagiotakos, D. B. (2011). The effect of Mediterranean diet on metabolic syndrome and its components: A meta-analysis of 50 studies and 534,906 individuals. Journal of the American college of cardiology, 57(11), 1299-1313. https://doi.org/10.1016/j. jacc.2010.09.073.

Katz, D. L., \& Meller, S. (2014). Can we say what diet is best for health? Annual review of public health, 35, 83-103. https://doi.org/10.1146/annurev-publhealth-032013-182351.

Kelly, J. R., Minuto, C., Cryan, J. F., Clarke, G., \& Dinan, T. D. (2017). Cross-talk: The microbiota and neurodevelopmental disorders. Frontiers in neuroscience, 11, 490. https://doi.org/10.3389/fnins.2017.00490.

Keys, A., Fidanza, F., Karvonen, M. J., Kimura, N., \& Taylor, H. L. (1972). Indices of relative weight and obesity. Journal of chronic diseases, 25(6-7), 329-343. https://doi. org/10.1016/0021-9681(72)90027-6.

Keys, A., Mienotti, A., Karvonen, M. J., Aravanis, C., Blackburn, H., Buzina, R., ... Toshima, H. (1986). The diet and 15year death rate in the Seven Countries Study. American journal of epidemiology, 124(6), 903-915. https://doi.org/10.1093/oxfordjournals. aje.a114480.

Killinger, B. A., Madaj, Z., Sikora, J. W., Rey, N., Haas, A. J., Vepa, Y., ... Labrie, V. (2018). The vermiform appendix impacts the risk of developing Parkinson's disease. Science translational medicine, 10(465), eaar5280. https://doi.org/10.1126/scitranslmed.aar5280.

Kivipelto, M., Mangialasche, F., \& Ngandu, T. (2018). Lifestyle interventions to prevent cognitive impairment, dementia and Alzheimer disease. Nature reviews neurology, 14(11), 653-666. https://doi.org/10.1038/s41582-018-0070-3.

Kodama, S., Tanaka, S., Saito, K., Shu, M., Sone, Y., Onitake, F., ... Sone, H. (2007). Effect of aerobic exercise training on serum levels of high-density lipoprotein choles- 
terol: A meta-analysis. Archives of internal medicine, 167(10), 999-1008. https://doi. org/10.1001/archinte.167.10.999.

Lassale, C., Batty, G. D., Baghdadli, A., Jacka, F., Sánchez-Villegas, A., Kivimäki, M., \& Akbaraly, T. (2018). Healthy dietary indices and risk of depressive outcomes: a systematic review and meta-analysis of observational studies. Molecular psychiatry. https:// doi.org/10.1038/s41380-018-0237-8.

Lin, X., Zhang, X., Guo, J., Roberts, C. K., McKenzie, S., Wu, W. C., ... Song, Y. (2015). Effects of exercise training on cardiorespiratory fitness and biomarkers of cardiometabolic health: A systematic review and meta-analysis of randomized controlled trials. Journal of the American heart association., 4(7), e002014. https://doi.org/10.1161/ JAHA.115.002014.

Luciano, M., Corley, J., Cox, S. R., Valdés Hernández, M. C., Craig, L. C., Dickie, D. A., ... Deary, I. J. (2017). Mediterranean-type diet and brain structural change from 73 to 76 years in a Scottish cohort. Neurology, 88(5), 449-455. https://doi.org/10.1212/ WNL.0000000000003559.

Malakou, E., Linardakis, M., Armstrong, M.E.G., Zannidi, D., Foster, C., Johnson, L., \& Papadaki, A. (2018). The combined effect of promoting the Mediterranean diet and physical activity on metabolic risk factors in adults: a systematic review and meta-analysis of randomised controlled trials. Nutrients, 10(11), E1577. https://doi.org/10.3390/ nu10111577.

Martin, A., Booth, J. N., Laird, .Y, Sproule, J., Reilly, J. J., \& Saunders, D. H. (2018). Physical activity, diet and other behavioural interventions for improving cognition and school achievement in children and adolescents with obesity or overweight. Cochrane Database of Systematic Reviews 2018, Issue 3. Art. No.: CD009728. https://doi. org/10.1002/14651858.CD009728.pub4.

Martinez-Lacoba, R., Pardo-Garcia, I., Amo-Saus, E., \& Escribano-Sotos, F. (2018). Mediterranean diet and health outcomes: a systematic meta-review. European journal of public health, 28(5), 955-961. https://doi.org/10.1093/eurpub/cky113.

Martínez-Lapiscina, E. H., Clavero, P., Toledo, E., Estruch, R., Salas-Salvadó, J., San Julián, B., ... Martinez-Gonzalez, M. A. (2013). Mediterranean diet improves cognition: the PREDIMED-NAVARRA randomised trial. Journal of neurolology, neurosurgery and psychiatry, 84(12), 1318-1325. https://doi.org/10.1136/jnnp-2012-304792.

Nordmann, A. J., Suter-Zimmermann, K., Bucher, H. C., Shai, I., Tuttle, K. R., Estruch, R., \& Briel, M. (2011). Meta-analysis comparing Mediterranean to low-fat diets for modification of cardiovascular risk factors. American Journal of Medicine, 124(9), 841-851. https://doi.org/10.1016/j.amjmed.2011.04.024.

Papamichael, M. M., Itsiopoulos, C., Susanto, N. H., \& Erbas, B. (2017). Does adherence to the Mediterranean dietary pattern reduce asthma symptoms in children? A systematic review of observational studies. Public health Nutrition, 20(15), 2722-2734. https://doi.org/10.1017/S1368980017001823.

Papamichael, M. M., Katsardis, C., Lambert, K., Tsoukalas, D., Koutsilieris, M., Erbas, B., \& Itsiopoulos, C. (2019). Efficacy of a Mediterranean diet supplemented with fatty fish in ameliorating inflammation in paediatric asthma: a randomised controlled trial. Journal of human nutrition and dietetics. 32(2), 185-197. https://doi.org/10.1111/ jhn. 12609 . 
Polidori, M. C., Nelles, G., \& Pientka, l. (2010). Prevention of dementia: Focus on lifestyle. International Journal of Alzheimers's Disease, 2010, 393579. https://doi. org/10.4061/2010/393579.

Roberts, R. C., Farmer, C. B., \& Walker, C. K. (2018). The human brain microbiome; there are bacteria in our brains! Neuroscience Meeting, San Diego, California, U.S.A., Society for Neuroscience, Program No. 594.08. Retrieved from https://www.sfn.org/-/ media/SfN/Documents/NEW-SfN/Meetings/Neuroscience-2018/Sessions-and-Events/ Program/Book-5_Tuesday.pdf?la=en\&hash=C990B451CBAA8D44617A37A35C23C CC3DFB65C85.

Ryan, M. C., Itsiopoulos, C., Thodis, T., Ward, G., Trost, N., Hofferberth, S., ... Wilson, A. M. (2013). The Mediterranean diet improves hepatic steatosis and insulin sensitivity in individuals with non-alcoholic fatty liver disease. Journal of Hepatology, 59(1), 138143. https://doi.org/10.1016/j.jhep.2013.02.012.

Sampson, L. (1985). Food frequency questionnaires as a research instrument. Clinical Nutrition 4(3), 171-178.

Sarris, J., Logan, A. C., Akbaraly, T. N., Amminger, G. P., Balanzá-Martínez, V., Freeman, M. P., ... Jacka, F. N. (2015). Nutritional medicine as mainstream in psychiatry. The Lancet psychiatry, 2(3), 271-274. https://doi.org/10.1016/S2215-0366(14)00051-0.

Scarmeas, N., Stern, Y., Tang, M. X., Mayeux, R., \& Luchsinger, J. A. (2006). Mediterranean diet and risk for Alzheimer's disease. Annals of Neurology, 59(6), 912-921. https://doi.org/10.1002/ana.20854.

Schreiber, S., Vogel, J., Schwimmer, H. D., Marks, S. M., Schreiber, F., \& Jagust, W. (2016). Impact of lifestyle dimensions on brain pathology and cognition. Neurobiology of aging, 40, 164-172. https://doi.org/10.1016/j.neurobiolaging.2016.01.012.

Serra-Majem, L., Roman, B., \& Estruch, R. (2006). Scientific evidence of interventions using the Mediterranean diet: a systematic review. Nutrition Reviews, 64(Suppl. 1), S27-S47. https://doi.org/10.1111/j.1753-4887.2006.tb00232.x.

Sexton, P., Black, P., Metcalf, P., Wall, C. R., Ley, S., Wu, L., ... Kolbe, J. (2013). Influence of Mediterranean diet on asthma symptoms, lung function, and systemic inflammation: a randomized controlled trial. Journal of asthma, 50(1), 75-81. https://doi.org/1 0.3109/02770903.2012.740120.

Sofi, F., Cesari, F., Abbate, R., Gensini, G. F., \& Casini, A. (2008). Adherence to Mediterranean diet and health status: meta-analysis. BMJ, 337, a1344. https://doi.org/10.1136/ bmj.a1344.

Sofi, F., Abbate, R., Gensini, G. F., \& Casini, A. (2010). Accruing evidence on benefits of adherence to the Mediterranean diet on health: an updated systematic review and meta-analysis. American journal of clinical nutrition, 92(5), 1189-1196. https://doi. org/10.3945/ajen.2010.29673.

Sofi, F., Macchi, C., Abbate, R., Gensini, G. F., \& Casini, A. (2014). Mediterranean diet and health status: An updated meta-analysis and a proposal for a literature-based adherence score. Public health nutrition, 17(12), 2769-2782. https://doi.org/10.1017/ S1368980013003169.

Sotos-Prieto, M., Moreno-Franco, B., Ordovás, J. M., León, M., Casasnovas, J. A., \& Peñalvo, J. L. (2015). Design and development of an instrument to measure overall lifestyle habits for epidemiological research: the Mediterranean lifestyle (MEDLIFE) index. Public health butition, 18(6), 959-967. https://doi.org/10.1017/S1368980014001360. 
Staubo, S. C., Aakre, J. A., Vemuri, P., Syrjanen, J. A., Mielke, M. M., Geda, Y. E., ... Roberts, R. O. (2017). Mediterranean diet, micronutrients and macronutrients, and MRI measures of cortical thickness. Alzheimer's \& dementia, 13(2), 168-177. https:// doi.org/10.1016/j.jalz.2016.06.2359.

Strasser, B., Siebert, U., \& Schobersberger, W. (2010). Resistance training in the treatment of the metabolic syndrome: A systematic review and meta-analysis of the effect of resistance training on metabolic clustering in patients with abnormal glucose metabolism. Sports medicine, 40(5), 397-415. https://doi.org/10.2165/11531380-00000000000000 .

Thompson, F. E., \& Byers, T. (1994). Dietary assessment resource manual. Journal of nutrition, 124(S11), 2245S-2317S.

Trichopoulou, A., Bamia, C., \& Trichopoulos, D. (2009). Anatomy of health effects of Mediterranean diet: Greek EPIC prospective cohort study. BMJ, 338: b2337. https://doi. org/10.1136/bmj.b2337.

Trichopoulou, A., Martínez-González, M. A., Tong, T. Y., Forouhi, N. G., Khandelwal, S., Prabhakaran, D., ... de Lorgeril, M. (2014). Definitions and potential health benefits of the Mediterranean diet: views from experts around the world. BMC medicine, 12: 112. https://doi.org/10.1186/1741-7015-12-112.

United Nations Educational, Scientific and Cultural Organization (2010). Inscription of Mediterranean diet on the Representative List of the Intangible Heritage of Humanity. Intergovernmental committee for the safeguarding of the intangible cultural heritage. Paris: UNESCO, Nomination file No. 00884.

van de Wouw, M., Boehme, M., Lyte, J.M., Wiley, N., Strain, C., O‘Sullivan, O., ... Cryan, J. F. (2018). Short-chain fatty acids: microbial metabolites that alleviate stressinduced brain-gut axis alterations. Journal of physiology, 596(20), 4923-4944. https:// doi.org/10.1113/JP276431.

Yannakoulia, M., Kontogianni, M., \& Scarmeas, N. (2015). Cognitive health and Mediterranean Diet: Just diet or lifestyle pattern? Ageing research reviews, 20, 74-78. https:// doi.org/10.1016/j.arr.2014.10.003.

Ye, X., Scott, T., Gao, X., Maras, J. E., Bakun, P. J., \& Tucker, K. L. (2013). Mediterranean diet, healthy eating index 2005, and cognitive function in middle-aged and older Puerto Rican adults. Journal of the academy of nutrition and dietetics, 113(2), 276-281. https://doi.org/10.1016/j.jand.2012.10.014.

Zamora-Ros, R., Serafini, M., Estruch, R., Lamuela-Raventós, R. M., MartínezGonzález, M. A., Salas-Salvadó, J., ... Andres-Lacueva, C. (2013). Mediterranean diet and non enzymatic antioxidant capacity in the PREDIMED study: Evidence for a mechanism of antioxidant tuning. Nutrition, metabolism, and cardiovascular diseases, 23(12), 1167-1174. https://doi.org/10.1016/j.numecd.2012.12.008.

Zell, M., \& Grundmann, O. (2012). An orthomolecular approach to the prevention and treatment of psychiatric disorders. Advances in mind-body medicine, 26(2), 14-28.

Zhao, C., Noble, J. M., Marder, K., Hartman, J. S., Gu, Y., \& Scarmaes, N. (2018). Dietary patterns, physical activity, sleep, and risk for dementia and cognitive decline. Current nutrition reports, 7(4), 335-345. https://doi.org/10.1007/s13668-018-0247-9. 